Ann. Biol. anim. Bioch. Biophys., 1979, 19 (1A), 91-101.

\title{
Solanum glaucophyllum in pregnant cows. Effect on colostrum mineral composition and plasma calcium and phosphorus levels in dams and newborn calves
}

\author{
par R. ROUX, Marie-Jeanne DAVICCO, B. J. CARRILLO *, J.-P. BARLET ( ${ }^{1}$ ) \\ Laboratoire des Maladies métaboliques, I.N.R.A. \\ Theix, St Genès Champanelle, 63110 Beaumont \\ * C.I.C.V., I.N.T.A., Castelar, Argentina.
}

Summary. Two successive experiments were carried out on cows at the end of gestation. For several days before calving they were orally fed dried ground leaves of Solanum glaucophyllum $(\mathrm{Sg})$ (a solanaceous plant of South America) containing a sterolglycoside of 1,25-dihydroxycholecalciferol, the biologically active metabolite of vitamin D. In Experiment I, Sg was administered for 7 days to 4 Jersey cows ( $34 \mathrm{~g}$ per animal per day) from days 8 to 2 before calving. This treatment significantly inhibited the drop in calcium and phosphate levels associated with parturition in cows. Colostrum levels of calcium $(3.8 \pm 0.6 \mathrm{~g} / \mathrm{l})$, mineral phosphorus $(1.97 \pm 0.24 \mathrm{~g} / \mathrm{l})$ and magnesium $(0.61 \pm 0.04 \mathrm{~g} / \mathrm{l})$ sampled in the 4 cows studied during the first milking after calving were significantly higher than those sampled in the same conditions in 4 controls (calcium : $2.2 \pm 0.3 \mathrm{~g} / \mathrm{l} ;$ mineral phosphorus : $0.69 \pm 0.05 \mathrm{~g} / \mathrm{l}$; magnesium : $0.21 \pm 0.02 \mathrm{~g} / \mathrm{l})$. In Experiment II, $\mathrm{Sg}$ was distributed in the concentrated ration for 4 days (days 6 to 3 before calving) to 19 Holstein $\times$ Friesian cows (25 g per animal per day). This treatment significantly depressed the hypocalcemia and hypophospatemia associated with parturition in cows. Moreover, the calcium level at birth in the 19 calves of treated cows $(12.2 \pm 0.3 \mathrm{mg} / \mathrm{dl})$ was significantly higher than that in the 15 control calves $(10.6 \pm 0.5 \mathrm{mg} / \mathrm{dl})$.

Various steroids have been identified in higher plants. Hence the roots and the leaves of Dactylis glomerata possess an antirachitic activity connected with their vitamin D content (Raoul ef al., 1968). Trisetum flavescens, a graminacea abundant in some pastures in the Bavarian and Austrian Alps, induces a syndrome known as «enzootic calcinosis » in grazing cattle. This is characterized by an important loss of weight, hyperphosphataemia, abherent calcifications in the cardiovascular system, the lungs, the kidneys and the flexor tendons of limbs, and by distortions of the joints (Dirksen ef al., 1975). This syndrome seems to be due to the presence in Trisetum flavescens of an analog to 1,25-dihydroxycholecalciferol (Peterlik, Regal and Köhler, 1977) $\left(1,25-(\mathrm{OH})_{2}-D_{3}\right)$, the biologically active metabolite of vitamin $D_{3}$ (De Luca, 1974). The family of Solanaceae seems to be well provided in derivatives of this vitamin. Thus Solanum sodomaeum has been mentioned in connection with « Naahelu disease »

(1) Correspondence to : J.-P. Barlet, I.N.R.A., Theix, 63110 Beaumont, France. 
which affects cattle ih Hawaii (Ross ef al., 1971), and whose clinical and biochemical symptoms are similar to those observed in alpine enzootic calcinosis (Lynd ef al., 1965). In Florida, Cestrum diurnum causes hypercalcaemia and tissue calcinosis in cattle (Krook et al., 1975a) and horses (Krook et al., 1975b). This domestic shrub contains an active principle which, like $1,25-(\mathrm{OH})_{2}-D_{3}$, prevents the inhibition of intestinal calcium absorption induced by strontium (Wasserman, Corradino and Krook, 1975). In the same way, the wasting disease of grazing animals, known as «Enteque seco » in Argentina (Worker and Carillo, 1967) and as «Espichamento » in Brazil (Döbereiner ef al., 1971), results from the ingestion of Solanum glaucophyllum $(\mathrm{Sg})$ (also known as Solanum malacoxylon). The leaves of $\mathrm{Sg}$ contain a steroid whose chemical properties and biological effects are very similar to those of $1,25-(\mathrm{OH})_{2}-\mathrm{D}_{3}$. Thus, in chicks, $\mathrm{Sg}$ increases intestinal calcium absorption by stimulating the duodenal synthesis of calcium-binding protein, even in birds given a strontium-rich diet (Wasserman, 1974). It has been demonstrated that strontium inhibits renal $1 \alpha$-hydroxylase activity, allowing the sole derivatives, already hydroxylated on carbon 1 , to retain a biological activity (Omdahl and De Luca, 1971). Sg is equally active in the nephrectomized (Walling and Kimberg, 1975a) or diabetic rat (Schneider, Wasserman and Schedl, 1975). These two observations confirm that the biological ativity of the vitamin analog present in the plant is not linked with the hydroxylation of carbon in position 1. An active aqueous extract from $\mathrm{Sg}$ leaves treated with $\beta$-glycosidase liberates a soluble substance into organic solvents. This substance migrates with $1,25-(\mathrm{OH})_{2}-\mathrm{D}_{3}$ on chromatography columns and, after ultra-violet absorption and mass spectrometry, emerges as identical to this metabolite (Peterlik et al., 1976 ; Wasserman et al., 1976); it inhibits renal $1 \alpha$-hydroxylase activity in the chicken as intensively as 1,25-(OH $)_{2}-D_{3}$ (Procsal ef al., 1976). Furthermore, in vitro an aqueous extract from $\mathrm{Sg}$ leaves stimulates duodenal calcium transport (Corradino and Wasserman, 1974) and bone resorption (Puche and Locatto, 1974). Thus the calcinogenic factor present in $\mathrm{Sg}$ is now considered to be 1,25-(OH) $)_{2}-D_{3}$-glycoside (Wasserman et al., 1976).

In the bovine, the intramuscular injection of $1,25-(\mathrm{OH})_{2}-\mathrm{D}_{3}$ induces significant hypercalcaemia and hyperphosphataemia (Capen, Hoffsis and Norman, 1977). Similar results have been obtained with $1 \alpha$-hydroxycholecalciferol (Barlet, 1975), a synthetic derivative obtained from cholesterol, whose structure differs from that of $1,25-(\mathrm{OH})_{2}-D_{3}$ only by the absence of an hydroxyl group in position 25 (Holick ef al., 1973). Furthermore, when injected into the cow before calving, $1 \alpha$-hydroxycholecalciferol prevents the fall in plasma calcium and phosphate levels occurring in this animal at the time of parturition (Sansom et al., 1976 ; Barlet, 1977 ; Gast et al., 1977 ; Sachs ef al., 1977). It therefore seemed interesting to study the influence of Sg (given orally to the cow at the end of gestation) on plasma calcium and phosphate levels in the dam and the newborn calf at the time of parturition, and on the mineral composition of colostrum. We report the results here.

\section{Materials and methods.}

Two successive experiments were carried out. In experiment I we studied the effect of a daily dose of $\mathrm{Sg}$ ( $35 \mathrm{~g}$ of dried powdered leaves mixed with $1 \mathrm{I}$ of water) 
on the plasma calcium, magnesium and phosphate levels and on the colostrum mineral composition of 4 Jersey cows in 3rd or 4th lactation. The $\mathrm{Sg}$ was given per os from days 8 to 2 before parturition; the 4 controls received 11 of water by the same way. The 8 animals were fed hay and grain concentrate. Thus, the approximate daily intake of each cow was $50 \mathrm{~g}$ of calcium, $55 \mathrm{~g}$ of inorganic phosphorus and $35 \mathrm{~g}$ of magnesium.

In experiment II, from days 6 to 3 before parturition, we fed $\mathrm{Sg}(25 \mathrm{~g}$ of dried powdered leaves given as a mixture with the ration concentrate) to 19 Holstein $x$ Friesian cows in 3rd, 4th or 5th lactation, and observed its effect on the plasma calcium, magnesium and phosphate levels in the dams and newborn calves. These 19 cows and 15 randomly chosen controls received a daily ration providing each one with $80 \mathrm{~g}$ of calcium, $75 \mathrm{~g}$ of inorganic phosphorus and $55 \mathrm{~g}$ of magnesium. The total dry matter ingested by the 34 animals was measured daily.

During both experiments, each cow was mechanically milked immediately after parturition. The daily milk production (milk containing 4 p. 100 fat from 2 daily milkings) was measured (table 1). In experiment I a colostrum sample was collected from the first 6 milkings after parturition. In all cows blood samples were taken daily at $9 \mathrm{a} . \mathrm{m}$. and at the time of parturition. In the 34 newborn calves used in experiment II, blood samples were collected at birth and $24 \mathrm{hrs}$ after delivery. Each blood sample was taken with a heparinized syringe from the external jugular vein and centrifuged. The plasma was frozen until analysis. Calcium and magnesium were measured by atomic absorption spectrophotometry (Perkin Elmer 420) in plasma and in colostrum. Inorganic phosphorus was determined by colorimetry (Technicon autoanalyser).

TABLE 1

Division of the animals, treatments, milk production and ingestion of dry matter

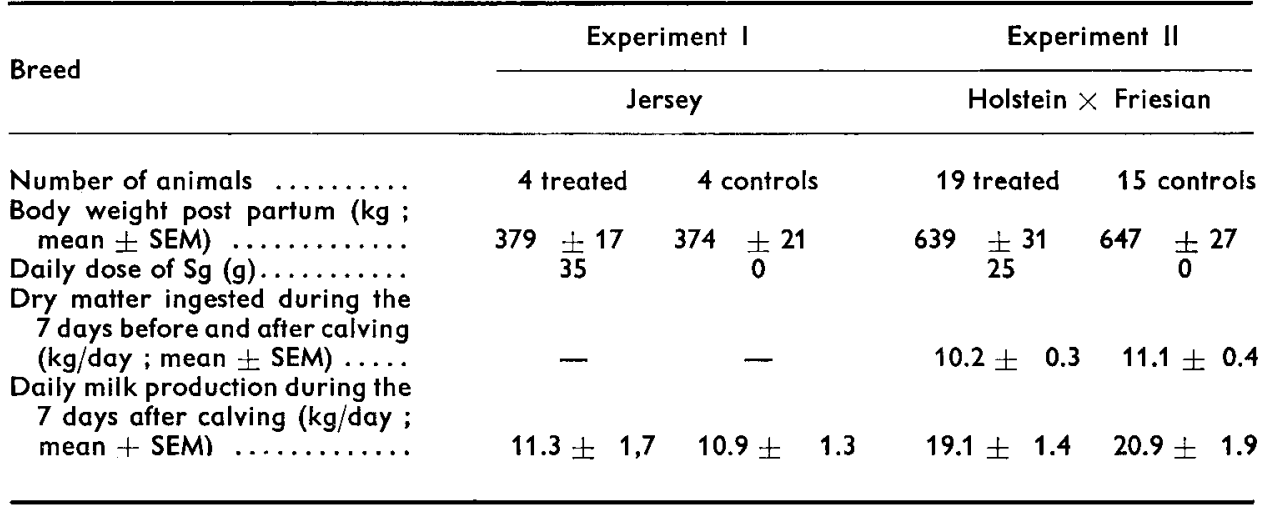

\section{Results.}

In the 23 treated cows, the ingestion of $\mathrm{Sg}$ significantly inhibited the hypocalcaemia and hypophosphataemia occurring at parturition (fig. 1 and 2). In the Holstein $\times$ Friesian cows, from 24 hrs after the first dose of $\mathrm{Sg}$ until the 6th day after the last 
treatment, plasma calcium and phosphate concentrations in the 19 treated animals were significantly higher than those of controls (fig. 2). Similarly, plasma calcium and phosphate levels in the 4 treated Jersey cows were significantly higher than those measured in controls from the 48th hr after the beginning of the treatment until the 4th day after its termination (fig. 1).
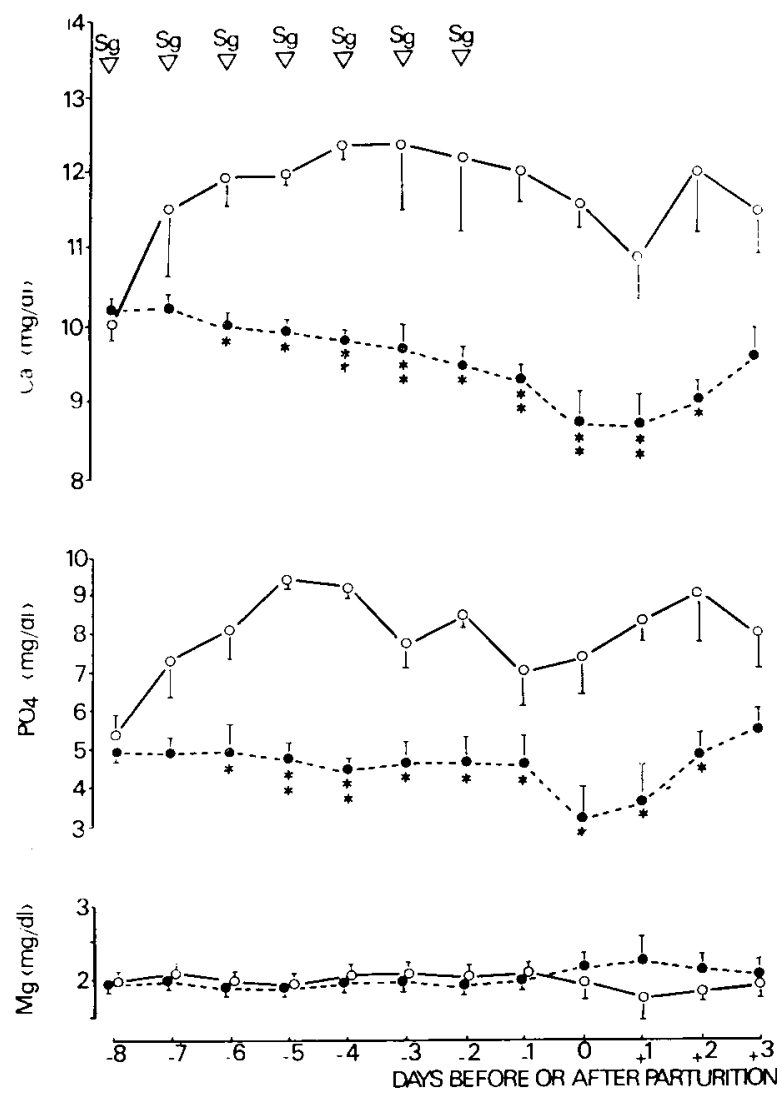

FIG. 1. - Influence of the ingestion of Solanum glaucophyllum $(\mathrm{Sg})(35 \mathrm{~g} / \mathrm{animal} /$ day for 7 days) on plasma calcium $(\mathrm{Ca})$, phosphate $\left(\mathrm{PO}_{4}\right)$ and magnesium $(\mathrm{Mg})$ levels in 4 pregnant jersey cows $(0-0)$ (๑- - - controls) (mean \pm SEM). The Student's $t$ test was used to compare simultaneously each parameter measured in the treated and control cows $\left({ }^{*} P<0.05 ;{ }^{* *} P<0.01\right)$.

At birth, the plasma calcium level $(12.2 \pm 0.3 \mathrm{mg} / \mathrm{dl})$ of the 19 calves born from the Holstein $\times$ Friesian treated cows was significantly higher than that $(10.6 \pm 0.5 \mathrm{mg}$ /d) of the 15 calves born from the controls. This difference between the two groups of calves disappeared 24 hrs after birth. Plasma phosphate and magnesium levels in newborn calves were not significantly changed when the cows ingested $\mathrm{Sg}$ (fig. 2).

At the first milking after parturition the level of calcium in the colostrum $(3.8$ $\pm 0.6 \mathrm{~g} / \mathrm{l}$ ) from the 4 treated Jersey cows was significantly higher than in the colostrum of the 4 controls $(2.2 \pm 0.3 \mathrm{~g} / \mathrm{l})$. During the first two milkings the levels of inorganic phosphorus in the colostrum of the treated animals $(1.97 \pm 0.24$ and $1.57 \pm 0.13 \mathrm{~g} /$ 

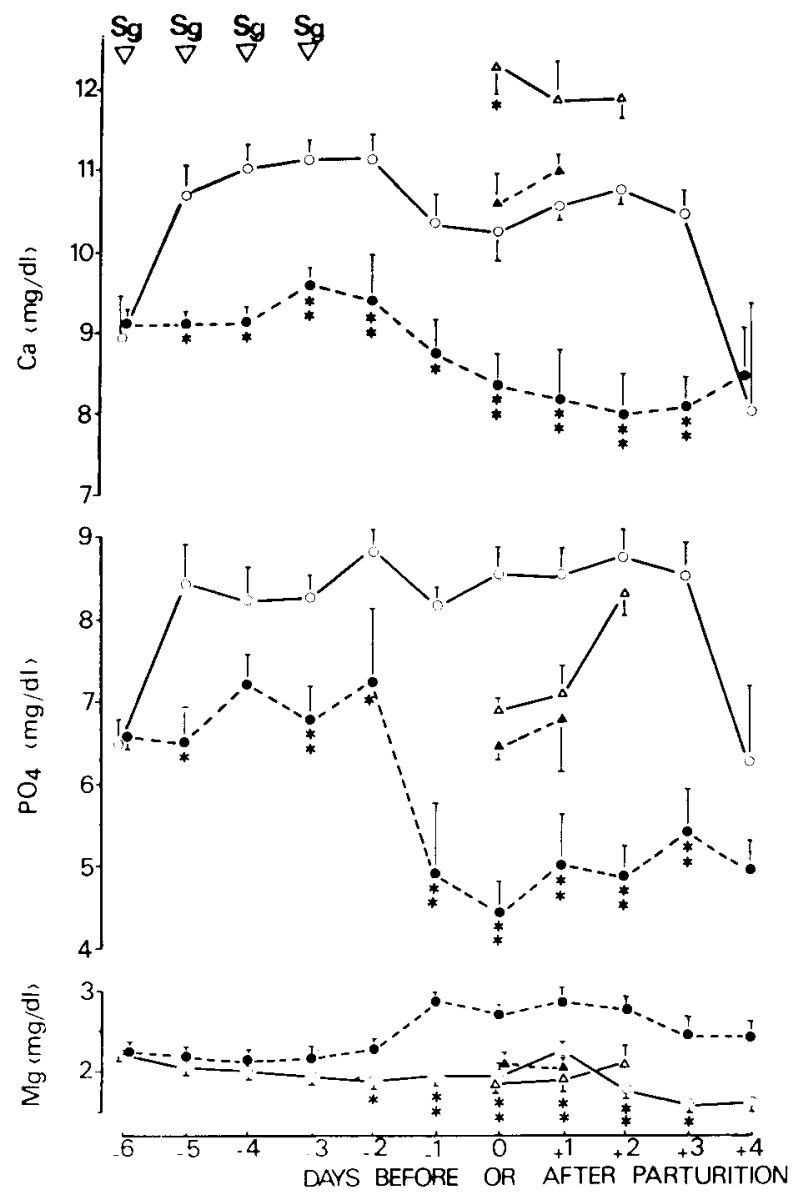

FIG. 2. - Influence of the ingestion of Solanum glaucophyllum $(\mathrm{Sg})(25 \mathrm{~g} /$ animal/day for 4 days) on plasma calcium $(\mathrm{Ca})$, phosphate $\left(\mathrm{PO}_{4}\right)$ and mognesium $(\mathrm{Mg})$ levels in 19 pregnant Holstein $\times$ Friesian cows $(\circ-0)$ and in their newborn calves $(\Delta-\Delta)(\bullet-\longrightarrow-\bullet$ control cows ; $\triangle-\longrightarrow$ calves of control cows) (mean \pm SEM).

The Student's $t$ test was used to compare simultaneously each parameter measured in the treated and control cows (or in the calves of the treated cows and those of the controls) $\left({ }^{*} P<0.05\right.$; $* * P<0.01)$.

respectively) was significantly higher than in the colostrum of the controls $(0.69$ \pm 0.05 and $0.79 \pm 0.07 \mathrm{~g} / \mathrm{l})$; the same wa strue of magnesium levels in the colostrum $(0.61 \pm 0.04$ and $0.46 \pm 0.07 \mathrm{~g} / /$ in the treated ones; $0.21 \pm 0.02$ and $0.20 \pm 0.03 \mathrm{~g} / \mathrm{l}$ in the controls) (fig. 3).

With the doses used, the ingestion of $\mathrm{Sg}$ did not seem to have any toxic effect on the 23 treated animals. During the experimental period, $\mathrm{Sg}$ did not alter in any significant way either the daily production of colostrum or the amounts of dry matter ingested (table 1). 

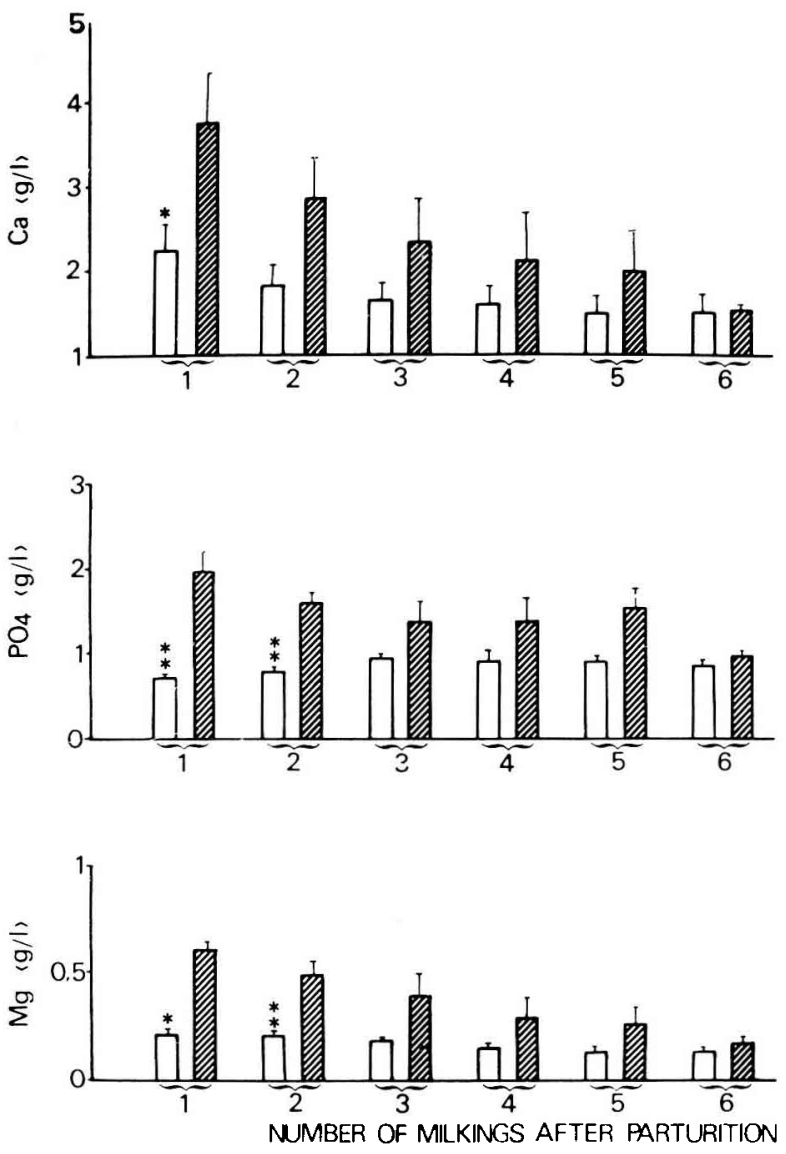

FIG. 3. - Influence of the ingestion of Solanum glaucophyllum ( $35 \mathrm{~g} / \mathrm{animal} / \mathrm{day}$, from days 8 to 2 before parturition) on the levels of calcium $(\mathrm{Ca})$, phosphate $\left(\mathrm{PO}_{4}\right)$ and magnesium $(\mathrm{Mg})$ in the colostrum of 4 Jersey cows (hatched bars) during the first 5 milkings after parturition (open bars : control cows) (mean \pm SEM).

The Student's t test was used to compare simultaneously each parameter in the colostrum of treated and control animals $\left({ }^{*} P<0.05 ;{ }^{* *} P<0.01\right)$.

\section{Discussion.}

In the two groups of animals used, the ingestion of $\mathrm{Sg}$ during the days before parturition inhibited the hypocalcaemia and hypophosphataemia occuring at this time (fig. 1 and 2). In the chicken, oral administration of $\mathrm{Sg}$ or of Cestrum diurnum induces a rapid, intense increase in 1,25-(OH) ${ }_{2}-D_{3}$ plasma level (Haussler et al., 1977). In the rat, a dose of $\mathrm{Sg}$ produces a more marked hypercalcaemia and hyperphosphataemia when it is given per os than when injected parenterally, as the liberation of the active steroid requires hydrolysis preferentially occurring in the intestine (Ladizesky, Mautalen and Camberos, 1974). For the same reason, an aqueous extract of $\mathrm{Sg}$ leaves is much more active after incubation with rumen juice (Boland ef al., 1976). Thus, the 
liberation of $1,25-(\mathrm{OH})_{2}-\mathrm{D}_{3}$ by $\mathrm{Sg}$ leaves in the digestive tract of the treated cows can easily explain the rise in plasma calcium and phosphate levels observed in the treated animals (fig. 1 and 2 ).

This hypercalcaemia and hyperphosphataemia may result both from a stimulation of intestinal absorption of calcium (Samson, Vagg and Dobereiner, 1971 ; O'Donnell and Smith, 1973 ; Lawson, Smith and Wilson, 1974 ; Wasserman, 1974 ; Canas et al., 1977) and inorganic phosphorus (Mautalen, 1972 ; Walling and Kimberg, $1975 b$ ) and from bone resorption. In Sg-treated rats, studies with ${ }^{45} \mathrm{Ca}$ have demonstrated a more rapid and intense turnover for calcium (Puche et al., 1976). Furthermore the addition of aqueous extract of $\mathrm{S} g$ to bone cultures in vitro induces a rise in the level of calcium and hydroxyproline in the medium (Puche and Locatto, 1974 ; Simonite, Morris and Collins, 1976).

The plasma magnesium level in the Holstein $\times$ Friesian cows treated with $\mathrm{Sg}$ is significantly lower than that of controls during the day before and the 3 days after parturition (fig. 2). In the dog, calciferol ingestion induces hypercalcaemia and hypomagnesemia, resulting essentially from a rise in the intracellular concentration of magnesium (Wallach et al., 1966). In the rat, the ingestion of $5000 \mathrm{lU}$ of calciferol increases the urinary excretion of magnesium (Lifshitz, Harrison and Harrisson, 1967). In the parturient cow there is an inverse relationship between plasma calcium and magnesium levels (Barlet, 1971).

At birth, the plasma calcium level in calves from Sg-treated Holstein $\times$ Friesian cows was significantly higher than that of calves from control cows (fig. 2). It has already been demonstrated that the ingestion of $\mathrm{Sg}$ by the cow during the last month of gestation (50 mg of Sg/kg b.w./day, for 6 days) induces a significant rise in plasma calcium and phosphate levels in both dam and foetus (Barlet et al., 1978). These result indicate that the analog to $1,25-(\mathrm{OH})_{2}-\mathrm{D}_{3}$ contained in $\mathrm{Sg}$ might stimulate the placental transfer of calcium from the mother to the foetus or that $1,25-(\mathrm{OH})_{2}-\mathrm{D}_{3}$ crosses the placenta and acts directly in the fœtus, inducing bone resorption and/or increasing intestinal absorption of calcium from foetal intestine (it has been shown in rats that foetal intestinal calcium-binding protein is vitamin D-dependent ; Garel, personnal communication).

In the cow, the colostrum is richer in mineral elements than is normal milk. A sharp decrease in the mineral level of the colostrum occurs during the first days after parturition (Guéguen, 1971). In the 4 Jersey cows, Sg does not change the decrease in the levels of calcium, inorganic phosphorus and magnesium in the colostrum during the first 6 milkings (fig. 3). In these 4 animals the levels of calcium, magnesium and inorganic phosphorus in the colostrum of the first milking are much higher that in the colostrum milked at the same time from control cows (fig. 3). The mineral composition of cow's milk, which is mainly determined by genetic factors, does not vary in relation to the diet (Guéguen, 1971). The levels of calcium and phosphorus in the milk of domestic ruminants is not under the control of parathyroid hormone and calcitonin since treatments such as parathyroidectomy or intravenous infusion of chelating agents in the cow (Pischke and Stott, 1964) or calcitonin deficiency induced by thyroidectomy (with thyroxine supplementation) in the goat (Barlet, 1974) do not alter milk composition. To our knowledge, no treatmen $t$ up to now given to the pregnant cow has changed the mineral composition of colostrum. The mammary glands 
of lactating rats maintained on a vitamin D-deficient diet supplemented with radios labelled cholecalciferol were found to mainly contain the unchanged vitamin 5 days after parturition (Weisman ef al., 1976). Furthermore these glands contained a specific binding protein for cholecalciferol. The suggested biological role of this protein is to selectively pick up the sterol from the maternal circulation to ensure its supply via the milk to the newborn (Edelstein, Eizenberg and Harell, 1976). In our experiments, inducing $1,25-(\mathrm{OH})_{2}-\mathrm{D}_{3}$ glycoside in the dam by $\mathrm{Sg}$ increases calcium levels both in the foetal (Barlet et al., 1979) and newborn calf and in the colostrum.

No clinical symptom was observed in either of the 2 groups of Sg-treated cows. The amounts of dry matter ingested and of colostrum produced during the experimental period were not significantly different in treated and control animals (table 1). The absence of toxic effects of $\mathrm{Sg}$ might result from the low doses used and from the short time of the treatment (4 to 7 days). In Argentina, cattle suffering from « Enteque seco » quickly recovered when transferred to pastures deprived of Sg (Worker and Carrillo, 1967).

$\mathrm{Sg}$ has already been used in therapeutic tests in patients suffering from hypoparathyroidism (Casco ef al., 1977) or from renal insufficiency during hemodialysis (Herrath ef al., 1975 ; Mautalen ef al., 1977 ; De Vernejoul, Mautalen and Miravet, 1978). Thus $\mathrm{Sg}$ might be used efficiently in the prophylaxis of parturient hypocalcaemia in dairy cows. This solanaceous plant offers a natural source of water-soluble 1,25$(\mathrm{OH})_{2}-D_{3}$. Furthermore the glycosidic molecules linked to the sterol prevent a too rapid liberation of it, and the intestinal mucosa of the animals ingesting $\mathrm{Sg}$ is exposed for a relatively long time to the active metabolite (Miravet et al., 1977). It can therefore be assumed that therapeutic applications of $\mathrm{Sg}$ will be widely considered in the future.

Reçu en juillet 1978.

Acceptè en septembre 1978.

Acknowledgments. - The Holstein $\times$ Friesian cows used in this experiment belong to the Laboratoire de Production laitière. The authors wish to thank R. Dabert, E. Logeais and B. Marquis for their help in the management of the animals.

Résumé. Au cours de 2 expériences successives des vaches en fin de gestation ont reçu par voie orale, pendant quelques jours avant la parturition, des feuilles séchées et broyées de Solanum glaucophyllum (Sg) (Solanée d'Amérique du Sud) qui renferment un stérolglycoside du 1,25-dihydroxycholécalciférol, métabolite biologiquement actif de la vitamine $D_{3}$.

Dans l'expérience I, $\mathrm{Sg}$ a été administré pendant 7 jours à 4 vaches Jersiaises $(35 \mathrm{~g}$ par animal et par jour, du $8^{\mathrm{e}}$ au $2^{\mathrm{e}}$ jour précédant le vêlage). Ce traitement inhibait de façon significative la baisse de la calcémie et de la phosphatémie associée à la parturition chez les vaches. De plus, la teneur en calcium $(3,8 \pm 0,6 \mathrm{~g} / \mathrm{l})$, en phosphore minéral $(1,97 \pm 0,24 \mathrm{~g} / \mathrm{l})$ et en magnésium $(0,61 \pm 0,04 \mathrm{~g} / \mathrm{l})$ du colostrum prélevé au cours de la première traite effectuée immédiatement après vêlage chez les 4 vaches traitées, était significativement supérieure à celle du colostrum prélevé dans les mêmes conditions chez 4 témoins où elle était respectivement de $2,2 \pm 0,3 \mathrm{~g} / \mathrm{l}$ pour le calcium, $0,69 \pm 0,05 \mathrm{~g} / 1$ pour le phosphore minéral et $0,21 \pm 0,02 \mathrm{~g} / \mathrm{l}$ pour le magnésium.

Dans l'expérience II, $\mathrm{Sg}$ a été distribué, mélangé à la ration de concentré, pendant 4 jours (du $6^{\mathrm{e}}$ au $3^{\mathrm{e}}$ jour précédant le vêlage) à 19 vaches Holstein $\times$ Frisonnes $(25 \mathrm{~g}$ de $\mathrm{Sg}$ par animal et par jour). Ce traitement inhibait de façon significative l'hypocalcémie et 
l'hypophosphatémie associées à la parturition chez ces animaux. En outre, à la naissance, la calcémie $(12,2 \pm 0,3 \mathrm{mg} / \mathrm{dl})$ des 19 veaux issus des vaches traitées était significativement supérieure à celle $(10,6 \pm 0,5 \mathrm{mg} / \mathrm{dl})$ des 15 vequx nés de vaches témoins.

\section{Références}

BARLET J.-P., 1971. Rôle de la calcitonine dans la régulation du métabolisme phosphocalcique des ruminants. Cas particulier : le syndrome vitulaire de la vache laitière. Thèse Doct. Etat Sci. nat., Univ. Clermont-Ferrand, C.N.R.S. AO 6020.

BARLET J.-P., 1974. Rôle physiologique de la calcitonine chez la chèvre gestante ou allaitante. Ann. Biol. anim. Bioch. Biophys., 14, 447-457.

BARLET J.-P., 1975. Influence du $1 \alpha$-hydroxycholécalciférol sur la calcémie et la phosphatémie des bovins. C. R. Acad. Sci. Paris, série D, 281, 1497-1500.

BARLET J.-P., 1977. Prophylaxie et thérapeutique de l'hypocalcémie vitulaire par les isomères ou les métabolites de la vitamine D. II. Le $1 \alpha$-hydroxycholécalciférol. Ann. Biol. anim. Bioch. Biophys., 17, 363-371.

BARLET J.-P., DAVICCO M. J., LEFAIVRE J., CARRILLO B. J., 1979. Fetal blood calcium response to maternal hypercalcemia induced in the cow by calcium infusion or by Solanum glaucophyllum ingestion. Horm. Metab. Res., 11 (sous presse).

BINGLEY J. B., RUKSAN B. E., CARRILLO B. J., 1976. Serum calcium fractions in sheep treated with Solanum malacoxylon. Res. Vef. Sci., 21, 121-122.

BOLAND R. L., SKLIAR M. I., BOLAND A. R., DE CAPILLO J., RUKSAN B., 1976. Modification del principo activo del Solanum malacoxylon mediante incubation con liquido ruminal. Medicina (Buenos Aires), 36, 323-329.

CANAS F. M., ORTIZ O. E., ASTEGgIANO C. A., PEREIRA R. D., 1977 . Effects of Solanum malacoxylon extract on rachitic chicks. Comparative study with vitamin $\mathrm{D}_{3}$. Calcif. Tiss. Res., 23, 297-302.

CAPEN C. C., HOFFSIS G. F., NORMAN A. W., 1977. Dose-response of 1,25-dihydroxycholecalciferol on serum calcium and phosphorus, urine electrolytes and hydroxyproline excretion in dairy cattle, 565-567. In NORMAN A. W., SCHAEFER K., COBURN J. W., DE LUCA H. F., FRASER D., GRIGOLEIT H. G., HERRATH D. V., Vitamin D. Biochemical, chemical and clinical aspects related to calcium metabolism. Walter de Gruyter, Berlin.

CASCO C., FERRARO C., LADIZESKY M., MAN Z., GHIRINGHELLI W., CABREJAS M., MAUTALEN C. A., 1977. Effects of Solanum malacoxylon in hypoparathyroidism, 759-761. In NORMAN A. W., SCHAEFER K., COBURN J. W., DE LUCA H. F., FRASER D., GRIGOLEIT H. G., HERRATH D. V., Vitamin D. Biochemical, chemical and clinical aspects related to calcium metabolism. Walter de Gruyter, Berlin.

CORRADINO R. A., WASSERMAN R. H., 1974. 1,25-dihydroxcholecalciferol-like activity of Solanum malacoxylon extract on calcium transport. Nature, 252, 716-718.

DE LUCA H. F., 1974. Vitamin D : the vitamin and the hormone. Fed. Proc., 33, 2211-2219.

DE VERNEJOUL M. C., MAUTALEN C. A., MIRAVET L., 1978. Le Solanum malacoxylon : de la plante toxique à l'agent thérapeutique. Nouv. Presse méd., 7, 1941-1943.

DIRKSEN G., PLANK P., HANICHEN T., SIMON U., 1975. Experimental investigations on the etiology of an enzootic calcinosis in cattle, 697-702. In NORMAN A. W., SCHAEFER K., GRIGOLEIT H. G., HERRATH D. V., RITZ E., Vitamin D and problems related to uremic bone disease. Walter de Gruyter, Berlin.

DOBEREINER J., TOKARINA C. H., DA COSTA J. B. D., CAMPOS J. L. E., DAYRELL M. D., 1971. « Espichamento », intoxicacao de bovinos por Solanum malacoxylon, no pastaral de mato grosso. Pesq. agropoc. Bras., Ser. Vet., 6, 91-117.

EDELSTEIN S., EIZENBERG Z., HARELL A., 1976. Specific binding-protein for cholecalciferol in mammary glands of lactating rats. Febs Lefters, 62, 245-247.

GAST D. R., MARQUARDT J. P., JORGENSEN N. A., DE LUCA H. F., 1977. Efficacy and safety of $1 \alpha$-hydroxyvitamin $D_{3}$ for prevention of parturient paresis. J. Dairy Sci., 60, 19101920. 
GUÉGUEN L., 1971. La composition minérale du lait et son adaptation aux besoins minéraux du jeune. Ann. Nutr. Alim., 25, A335-A381.

HAUSSLER M. R., HUGHES M. R., PIKES J. W., Mc CAIN T. A., 1977. Radioligand receptor assay for 1,25-dihydroxyvitamin $D$ : biochemical, physiologic and clinical applications, 472482. In NORMAN A. W., SCHAEFER K., COBURN J. W., DE LUCA H. F., FRASER D., GRIGOLEIT H. G., HERRATH D. V., Vitamin D. Biochemical, chemical and clinical aspects related to calcium metabolism, Walter de Gruyter, Berlin.

HERRATH D. V., SCHAEFER K., KRAFT D., OFFERMANN G., 1975. Effect of Solanum malacoxylon on calcium metabolism in experimental uramia and in uremic patients, 703-708. In NOR-

MAN A. W., SCHAEFER K., GRIGOLEIT H. G., HERRATH D. V., RITZ E., Vitomin D and problems related to uremic bone disease. Walter de Gruyter, Berlin.

HOLICK M. F., SEMMLER E. J., SCHNOES H. K., DE LUCA H. F., 1973. $1 \alpha$-hydroxy-derivative of vitamin $D_{3}$ : a highly potent analog of $1 \alpha, 25$-hydroxyvitamin $D_{3}$. Science, 180, 190-191.

KROOK L., WASSERMAN R. H., MC ENTEE K., BROKKEN T. D., TEIGLAND M. B., 1975a. Cestrum diurnum poisoning in Florida cattle. Cornell Vet., 65, 557-575.

KROOK L., WASSERMAN R. H., SHIVELY J. N., TASHJIAN A. H., BROKKEN T. D., MORTON J. F., 1975b. Hypercalcemia and calcinosis in Florida horses : implication of the shrub, Cestrum diurnum, as the causative agent. Cornell Vet., 65, 26-56.

LADIZESKY M., MAUTALEN C. A., CAMBEROS H., 1974. Solanum malacoxylon : comparacion de su actividad biologica al administrarlo por via oral o parenteral en animales de laboratorio. Medicina (Buenos Aires), 34, 127-132.

LAWSON D. E. M., SMITH M. W., WILSON P. W., 1974. Relationship of calcium binding protein synthesis in chick and rat intestine in response to Solanum malacoxylon. Febs Letfers, 45, $122-125$.

LIFSHITZ F., HARRISON H. C., HARRISON H. E., 1967. Effects of vitamin D on magnesium metabolism in rats. Endocrinology, 81, 849-853.

LYND F. T., WILLERS E. H., WEIGHT L. A., GEBAUER P. W., 1965. Bovine arteriosclerosis in Hawaii. Amer. J. vel. Res., 26, 1344-1349.

MAUTALEN C, A., 1972. Mechanism of action of Solanum malacoxylon upon calcium and phosphate metabolism in the Rabbit. Endocrinology, 90, 563-567.

MAUTALEN C. A., FERRARO C., CABREJAS M., LANDI E., GOTLIEB D., 1977 . Effects of Solanum malacoxylon on calcium metabolism in patients with chronic renal failure. Calcif. Tiss. Res., 225, 534-537.

MIRAVET L., CARRÉ M., FISHER-FERRARO C., MAUTALEN C., 1977. Action of Solanum malacoxylon on intestinal calcium transport in vitamin D-deficient prednisolone treated rats. J. clin. Endocrinol. Metab., 45, 1230-1234.

O'DONNELL J. M., SMITH M. W., 1973. Vitamin D-like action of Solanum malacoxylon on calcium transport by rat intestine. Nature, 244, 357-358.

OMDAHL J. L., DE LUCA H. F., 1971. Strontium-induced rickets : metabolic basis. Nature, 174, 949-951.

PETERLIK M., BURSAC K., HAUSSLER M. R., HUGHES M. R., WASSERMAN R. H., 1976. Further evidence for the 1,25-dihydroxyvitamin D-like activity of Solanum malacoxylon. Biochem. biophys. Res. Comm., 70, 797-804.

PETERLIK M., REGAL D. S., KÖHLER H., 1977. Evidence for a 1,25-dihydroxy-vitamin D-like activity in Trisetum flavescens : possible cause for calcinosis in grazing animals. Biochem. biophys. Res. Comm., 77, 775-781.

PISCHKE L. D., STOTT G. H., 1964. Relationship of the bovine parathyroids to calcium and phosphorus in milk. J. Dairy Sci., 47, 698.

PROCSAL D. A., HENRY H. L., HENDRICKSOH T., NORMAN A. W., 1976. $1 \alpha$, 25-dihydroxyvitamin $\mathrm{D}_{3}$-like component present in the plant Solanum glaucophyllum. Endocrinology, 99, 437-444.

PUCHE R. C. LOCATTO M. E., 1974. Effects of Solanum malacoxylon on embryonic bone in vitro and on isolated mitochondria. Calcif. Tiss. Res. 16, 219-226.

PUCHE R. C., LOCATTO M. E., FERRETTI J. L., FERNANDEZ M. C., ORSATTI M. B., VALENTI J. L., 1976. The effects of long term feeding of Solanum glaucophyllum to growing rats on $\mathrm{Ca}, \mathrm{Mg}, \mathrm{P}$ and bone metabolism. Calcif. Tiss. Res., 20, 105-119. 
RAOUL Y., LE BOULCH N., GOUNELLE J. C., MARNAY-gULAT C., OURISSON G., 1968. Isolement et caractérisation du cholécalciférol des végétaux supérieurs. Febs Letters, 1, 5962.

ROSS E., SIMPSON C. F., ROWLAND L. O., HARMS R. H., 1971. Toxicity of Solanum sodomaeum and Solanum malacoxylon to chicks. Poultry Sci., 50, 870-873.

SACHS M., BAR A., COHEN R., MAZUR Y., MAYER E., HURWITZ S., 1977. Use of $1 \alpha$-hydroxycholecalciferol in the prevention of bovine parturient paresis. Amer. J. vet. Res., 39, 20392041.

SANSOM B. F., VAGG M. J., DOBEREINER J., 1971. The effects of Solanum malacoxylon on calcium metabolism in cattle. Res. Vet. Sci., 12, 604-605.

SANSOM B. F., ALLEN W. M., DAVIES D. C., HOARE M. N., STENTON J. R., VAGG M. J., 1976. Use of $1 \alpha-\mathrm{OH}$ cholecalciferol in preventing post parturient hypocalcemia and its potential value for the prevention of milk fever in dairy cows. Vet. Record, 99, 310-312.

SCHNEIDER L. E., WASSERMAN R. H., SCHEDL H. P., 1975. Depressed duodenal calcium absorption in the diabetic rat : restoration by Solanum malacoxylon. Endocrinology, 97, 649653.

SIMONITE J. P., MORRIS K. L. M., COLLINS J. C., 1976. Induction of bone resorption in vitro by an extract of Solanum malacoxylon. J. Endocr., 68, 18P-19P.

WALLACH S., BELLAVIA J. V., SCHORR J., GAMPONIA P. J., 1966. Effect of vitamin D on tissue distribution and transport of electrolytes, ${ }^{47} \mathrm{Ca}$ and ${ }^{28} \mathrm{Mg}$. Endocrinology, 79, 773-782.

WALLING M. W., KIMBERG D. V., 1975a. Calcium absorption by intestine. Stimulation in vitamin D-deficient nephrectomized rats by Solanum glaucophyllum. Gostroenterology, 69, 200-205.

WALLING M. W., KIMBERG $D$. V., 1975b. Effects of 1,25 dihydroxyvitamin $D_{3}$ and Solanum glaucophyllum on ingested calcium and phosphate transport and on plasma $\mathrm{Ca}, \mathrm{Mg}$ and $\mathrm{P}$ levels in the rat. Endocrinology, 97, 1567-1575.

WASSERMAN R. H., 1974. Calcium absorption and calcium-binding protein synthesis: Solonum malacoxylon reverses strontium inhibition. Science, 183, 1092-1094.

WASSERMAN R. H., CORRADINO R. A., KROOK L. P., 1975. Cestrum diurnum : a domestic plant with 1,25-dihydroxycholecalciferol-like activity. Biochem. biophys. Res. Comm., 62, 8591.

WASSERMAN R. H., HENION J. D., HAUSSLER M. R., MC CAIN T. A., 1976. Calcinogenic factor in Solanum malacoxylon : evidence that it is 1,25 -dihydroxyvitamin $D_{3}$-glycoside. Science, 194, 853-855.

WEISMAN Y., SAPIR R., HARELL A., EDELSTEIN S., 1976. Maternal-perinatal interrelationships of vitamin D metabolism in rats. Biochim. biophys. Acta, 428, 388-395.

WORKER N. A., CARRILLO B. J., 1967. "Enteque seco », calcification and wasting in grazing animals in the Argentine. Nature, 215, 72-74. 